\title{
Detecting and identifying ectomycorrhizal fungi in New Zealand silver beech (Lophozonia menziesii, Nothofagaceae) forest: a case study
}

\author{
David A Orlovich ${ }^{\ddagger}$, Andy R Nilsen ${ }^{\ddagger}$, Suliana E Teasdale ${ }^{\ddagger}$, , Paul L Guy ${ }^{\ddagger}$, Tina C Summerfield ${ }^{\ddagger}$ \\ ‡ University of Otago, Dunedin, New Zealand \\ $\S$ AgResearch, Palmerston North, New Zealand
}

Corresponding author: David A Orlovich (david.orlovich@otago.ac.nz)

Received: 18 Apr 2018 | Published: 18 May 2018

Citation: Orlovich D, Nilsen A, Teasdale S, Guy P, Summerfield T (2018) Detecting and identifying ectomycorrhizal fungi in New Zealand silver beech (Lophozonia menziesii, Nothofagaceae) forest: a case study. Biodiversity Information Science and Standards 2: e25982. https://doi.org/10.3897/biss.2.25982

\section{Abstract}

Adventitious roots in canopy soils associated with silver beech (Lophozonia menziesii (Hook.f.) Heenan \& Smissen (Nothofagaceae)) form ectomycorrhizal associations. We used amplicon sequencing of the internal transcribed spacer 2 region to compare diversity of ectomycorrhizal fungal species in canopy and terrestrial sites. The study data are archived as an NCBI BioProject (accession PRJNA421209), with the raw DNA sequence reads available from the NCBI Sequence Read Archive SRA637723 Community composition of canopy ectomycorrhizal fungi was significantly different to the terrestrial community composition, with several abundant ectomycorrhizal species significantly more represented in the terrestrial soil than the canopy soil. Additionally, we found evidence that an introduced ectomycorrhizal species was present in these native forest soils. We identified OTUs in two ways: (i) by manually curated BLAST searching of the NCBI nr database, and (ii) by comparison with Species Hypotheses on UNITE v.7.2. We desired to make species identifications where we could be reasonably confident they were robust, but had to avoid making identifications when an incorrect name could have implications for biosecurity or our understanding of biodiversity and biogeography. We found some UNITE Species Hypotheses included sequences of more than one taxon, which we were able to 
separate and distinguish by phylogenetic analysis. Consequently we exercised caution in reporting names based on the Species Hypotheses.

Using data from this case study, we will illustrate the achievements and challenges faced in identifying species of ectomycorrhizal fungi from DNA barcodes. Most DNA sequences of ectomycorrhizal fungi matched closely New Zealand voucher specimens stored in either the New Zealand Fungal Herbarium (PDD) or the Otago Regional Herbarium (OTA), which facilitated the validation of identifications. In the case of PDD specimens, collection and DNA data were linked via the Systematics Collections Data database (https:// scd.landcareresearch.co.nz). We are working towards a similar database for OTA specimens, using the Specify 6 database platform.

\section{Presenting author}

David A Orlovich

\section{Grant title}

Canopy soil microhabitats: microbial communities take to the trees? 